Research Article

Check for updates

\section{OPEN ACCESS}

Received: Apr 8, 2020

Revised: May 20, 2020

Accepted: May 27, 2020

Correspondence to

Moon-Jeong Chang

Department of Food and Nutrition, Kookmin

University, 77 Jeongneung-ro, Seongbuk-gu,

Seoul 02707, Korea.

Tel: +82-2-910-4776

E-mail: cmoon@kookmin.ac.kr

*These authors contributed equally to this article.

(C) 2020 The Korean Nutrition Society

This is an Open Access article distributed

under the terms of the Creative Commons

Attribution Non-Commercial License (http://

creativecommons.org/licenses/by-nc/3.0/)

which permits unrestricted non-commercial

use, distribution, and reproduction in any

medium, provided the original work is properly

cited.

ORCID iDs

Ki Nam Kim (iD

https://orcid.org/0000-0002-9485-567X

Jung Sug Lee (iD)

https://orcid.org/0000-0001-8738-6409

Jee-Seon Shim (iD)

https://orcid.org/0000-0002-8671-3153

Hae Kyung Chung iD

https://orcid.org/0000-0002-1002-2399

Hae Rang Chung (iD

https://orcid.org/0000-0002-1026-3512

Moon-Jeong Chang (iD)

https://orcid.org/0000-0002-2880-6458

Funding

This research was supported by a grant (17162MFDS083) from Ministry of Food and Drug Safety in 2017.

\section{서울, 경기지역의 초등학생 대상 당 저감화에 관한 소비자 인식 및 관련 교육 효과 분석}

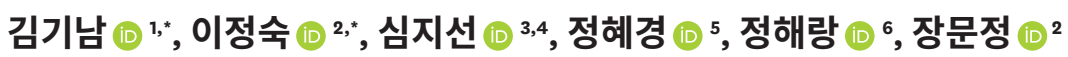

'대전대학교 식품영양학과

2국민대학교 식품영양학과

${ }^{3}$ 연세대학교 의과대학 예방의학교실

4연세대학교 의과대학 심뇌혈관 및 대사질환 원인연구센터

${ }^{5}$ 호서대학교 식품영양학과

${ }^{6}$ (주)영양과미래

\title{
Analysis of the consumer perception and related education effect on the reduction of sugar for elementary school students in Seoul and Gyeonggi-do
}

\section{Ki Nam Kim $(\mathbb{D})^{1, *}$, Jung Sug Lee $\mathbb{1}^{2, *}$, Jee-Seon Shim $\mathbb{1}^{3,4}$, Hae Kyung Chung $(\mathbb{D})^{5}$, Hae Rang Chung $\left(\mathbb{1}^{6}{ }^{6}\right.$, and Moon-Jeong Chang $\mathbb{( 1 0}^{2}$}

'Department of Food and Nutrition, Daejeon University, Daejeon 34520, Korea

${ }^{2}$ Department of Food and Nutrition, Kookmin University, Seoul 02707, Korea

${ }^{3}$ Department of Preventive Medicine, Yonsei University College of Medicine, Seoul 03722, Korea

${ }^{4}$ Cardiovascular and Metabolic Diseases Etiology Research Center, Yonsei University College of Medicine, Seoul 03722, Korea

${ }^{5}$ Department of Food and Nutrition, Hoseo University, Asan 31499, Korea

${ }^{6}$ Nutrition for the future (Inc), Seoul 08708, Korea

\section{ABSTRACT}

Purpose: This study examined the effects of nutritional education related to sugar in elementary school children on nutritional knowledge, attitude, and dietary behavior. Methods: A questionnaire survey on the knowledge, attitudes, and intake related to sugar was conducted on 572 students in grades $4-5$, who were attending five elementary schools in Seoul and Gyeonggi-do.

Results: Among the survey subjects, 270 (49.8\%) were cognitive in education, and 302 $(50.2 \%)$ were non-cognitive. The sugar-related knowledge score was 3.67 points in the cognitive education group, which was significantly higher than the 3.55 points in the noncognitive group. The rate of checking the sugar content in the nutrition label was $31.2 \%$ in the cognitive education group, which was significantly higher than in the non-cognitive group, $15.4 \%$. The cognitive education group had a higher intake frequency of unsweetened candy, jelly, and raw fruits, and higher sugar intake of unsweetened bread, white milk, and raw fruits than the non-cognitive group. In the case of the cognitive education group, the total 
Conflict of Interest

There are no financial or other issues that might lead to conflict of interest. knowledge score showed a positive correlation with the food behavior scores, and a negative correlation with the frequency of purchasing snacks after school, and the average sugar intake per day. In the cognitive education group only, the education of nutrition teachers was analyzed as a factor to reduce the total sugar intake. The cognitive group of sugar education tried to eat foods with a lower sugar content than the non-cognitive group, and nutrition education was an important factor affecting the sugar intake.

Conclusion: To reduce the sugar intake of elementary school students, it will be necessary to practice oriented-nutrition education by nutrition teachers continuously. In addition, it is important to develop and disseminate various types of nutrition education materials related to sugar that can be utilized easily by nutrition teachers.

Keywords: sugar, education, dietary habits, elementary student

\section{서론}

과도한 당류 섭취는 비만, 당뇨병, 고혈압, 심장질환, 뇌졸중 및 치아우식증 등의 발생위험을 높이는 것으로 알려져 있다 [1-4]. 국민건강영양조사 (2008-2011)에 따르면 가공식품의 발달 과 식생활의 서구화로 인해 당류 섭취는 꾸준히 증가되고 있으며, 특히 연령이 낮을수록 총 당류로부터 섭취되는 에너지 비율이 높은 것으로 보고되었다 [5]. 어린이 기호식품의 경우 당분 함량이 높은 식품들이 많다. 초등학생의 간식섭취실태를 조사한 Lee 등 [4]의 연구에서 아동들은 간식 선택에 있어 맛을 가장 중요하게 생각하고 있으며, 실제 주로 섭취하는 간식 류 역시 단순당류나 아이스크림, 탄산음료, 과자류 등이었다. 9-14세 한국 소아청소년 2,599 명을 대상으로 총 당류 섭취량을 조사한 최근 연구에 따르면, 남아 $46.6 \mathrm{~g}$, 여아 $54.3 \mathrm{~g}$ 으로 에 너지 섭취량 대비 당류 섭취량은 각각 $10.8 \%$ 와 $12.5 \%$ 였고, 당류의 주요 급원이 대부분 가공 식품들로, 당류식품이나 가당 음료가 총 당류 섭취량의 $50 \%$ 이상 기여했다는 점에서 소아청 소년들의 당 섭취에 대한 우려가 제기되고 있다 [6].

성장기 아동들에 있어 당류의 지나친 섭취는 미량영양소 섭취 부족과 영양불균형, 식사의 질 저하 문제를 야기할 수 있다. 제주지역 초등학생을 대상으로 한 연구에서 총 에너지의 $20 \%$ 이상 고당류 섭취 아동들의 경우 철분, 아연, 나이아신의 섭취가 유의적으로 낮은 것으로 보 고하고 있으며 [7], 충남 지역 초등학생을 대상으로 한 연구에서도 총 당류 섭취가 높을수록 단백질, 철분, 아연의 영양밀도가 낮아지는 것으로 보고하고 있어 [8], 아동기의 당류 섭취량 증가는 미량 영양소의 불균형을 초래할 수 있다. 이러한 영양섭취의 불균형은 성장기 어린이 의 건강에도 부정적인 영향을 미칠 수 있다.

다수의 국가에서 시행된 성장기 어린이를 대상으로 한 연구에서 가당음료 섭취량 증가는 체 질량지수 또는 비만율을 증가시키는 것으로 보고하고 있다 [9,10]. 또한 소아청소년을 대상 으로 한 국내 코호트 연구에서도 가당음료를 통한 당류 섭취는 초기 조사에서 대사증후군 발 생의 위험을 증가시켰으나 추적 관찰 시에는 관련성이 없는 것으로 보고하고 있으며 [11], 충 남지역 초등학생을 대상으로 한 연구에서도 당류 섭취량 증가는 과체중 및 비만에 영향을 미치지 않는 것으로 보고하고 있어 [8] 국내 어린이의 경우 총 당류 뿐만 아니라 가당 음료 를 통한 당 섭취량 증가는 비만 및 대사성질환에 미치는 영향이 미미한 것으로 보고되고 있 다. 그러나 ‘어린이.청소년의 환경 노출 및 건강실태 조사 (children's health and environmen- 
tal research)'에 참여한 초등학생을 대상으로 당 섭취와 주의력 결핍 과잉행동장애 (attention deficit hyperactivity disorder, $\mathrm{ADHD}$ ) 사이의 관련성을 분석한 결과, 식이패턴이 단음식군에 해당하는 경우 $\mathrm{ADHD}$ 발생의 위험이 1.59배 높게 나타났다 [12]. 또, 성인을 대상으로 한 연구 에서 가공식품을 통한 당류 섭취량이 하루 열량의 $10 \%$ 초과 시 비만, 고혈압 및 당뇨병 발생 의 위험이 $39 \%$ 이상 높아지는 것으로 보고하고 있다 [13].

아동기 올바른 식습관과 기호도 형성은 성인기 식습관의 기초가 되므로 아동을 대상으로 한 당류 섭취 저감화 정책 마련의 필요성이 대두되면서, 식품의약품안전처에서는 2007년 부터 가공식품의 당 함량 표시를 의무화하였고, 2008년 3월 ‘어린이 식생활안전관리특별법' 을 제정·공포하고 학교 구내와 학교 주변 $200 \mathrm{~m}$ 이내 지역을 '식품안전보호구역'으로 지정 하여 건강저해식품의 판매를 제한하고 있다 [14]. 식품의약품안전처에서는 2016년 4월 제1 차 (2016-2020) 당류 저감종합계획을 발표 [13]하고 국민 개개인의 식습관 및 인식개선의 일 환으로 어린이.청소년 당류 줄이기 교육을 위한 영양교육 프로그램을 개발하고 교육 자료를 보급하고 있다.

영양교육의 목적은 단순히 영양지식을 전달하기보다 실제 식생활에 적용하여 올바른 식행 동을 유도함으로써 바람직한 식습관을 갖출 수 있도록 하는데 있다. 이에 본 연구에서는 초 등학생을 대상으로 당류 관련 영양교육이 당류 섭취와 관련한 식행동에 미치는 효과를 파악 하기 위하여 당류 섭취와 관련된 영양지식과 영양태도, 관련 식행동 및 당류 식품의 섭취 빈 도를 조사하고자 하였다.

\section{연구방법}

\section{조사대상 및 기간}

본 연구 대상자는 서울 및 경기도 소재의 5 개 초등학교 학생을 대상으로 하였으며, 이들 초등 학교 중에는 식품의약품안전처에서 수행한 당 관련 영양교육사업에 참여한 학교가 포함되 었다. 설문조사는 2017년 9월 1일에서 22일 사이에 실시되었으며, 조사 대상 초등학교 4-5학 년에 재학중인 580명을 대상으로 설문조사를 실시하였다. 조사대상자 중 당 관련 영양교육 을 받았다고 응답한 교육인지군은 290 명으로 $46.6 \%$ 에 해당되었고, 교육을 받지 않았다고 응 답한 교육비인지군은 302명이었으며, 8 명은 무응답처리 되었는데, 별도로 ‘모르겠다'는 문 항을 두지 않아, 무응답의 경우 교육을 받았는지, 받지 않았는지 인지를 하지 못한 학생으로 추정되어 분석대상에서 제외하였다. 영양교사나 교과 담당 교사에 의해 전체 학생을 대상으 로 당류 섭취를 포함한 식생활 교육이 일괄적으로 수행되었음에도 불구하고 당류 섭취 관련 교육을 받지 않았다고 응답한 경우가 전체의 $50.2 \%$ 에 해당되어 이를 당류 섭취 교육에 대한 비인지군으로 분류하였고, 당류 섭취 관련 교육을 받았다고 응답한 경우를 인지군으로 분류 하였다. 본 연구는 대전대학교 생명연구윤리위원회의 승인을 거쳐 수행하였다 (IRB 승인번 호: 1040647-201706-HR-027-03).

\section{설문지 개발}

설문지는 일반 사항과 당류 섭취 관련 영양교육 경험 유무, 영양지식, 식생활 실천도, 식품섭 취빈도 조사 문항으로 구성되었으며, 통계전문가 및 영양학 전문가들의 자문을 거쳐 개발되 
었다. 설문조사지는 초등학생을 대상으로 한 조사임을 감안하여 조사시간이 10-20분 이내에 완료될 수 있도록 일반 사항을 포함하여 15 문항 이내로 구성하고자 하였고, 일반 사항은 학 년과 성별 외에 식생활에 영향을 미칠 수 있는 동거 가족에 대한 문항과 비만도 계산을 위한 키와 몸무게에 대한 문항으로 구성하였다. 영양지식에 관한 문항은 식품의약품안전처에서 2015-2016년 초등학생 3-4학년을 대상으로 수행한 당류 관련 시범 교육사업의 영양교육효과 평가지와 동일한 문항으로 구성하였고, 식생활 실천도는 식품의약품안전처에서 실시한 당 류 섭취에 대한 영양교육 내용을 바탕으로 영양표시 확인 여부, 당류 섭취와 관련된 평소 식 습관 6항목, 평소 음료 선택 습관, 간식 구입처와 빈도로 구성하였다. 당류 섭취에 영향을 줄 수 있는 요인들에 대한 문항으로 영양교육 경험과 인지도에 관한 문항을 추가하였다. 식품 섭취빈도는 어린이용 영양지수 설문지 [15]의 당류 식품 섭취 빈도에 사용된 준거 기간을 참 고로 하여 ‘국민 다소비 식품의 당류 DB 확보 및 조사 연구’ [16]의 6-11세 연령층의 주요 당류 급원 식품 순위 조사 결과를 바탕으로 항목을 구성하였다. 또한 아동들의 이해를 돕기 위해 당분 함량이 높은 제품과 당분 함량이 상대적으로 낮은 제품으로 분류하고 인터넷 쇼핑몰에 서 각 식품항목별로 판매량이 높은 대표 제품명 또는 일반명을 예로 들어 구성하였다. 설문 지 문항의 신뢰도 검증은 SPSS (ver. 18.0; SPSS Inc., Chicago, IL, USA)를 사용하였고, 본 조사 와 동일한 대상의 초등학교 4-5학년 30명을 대상으로 실시한 예비조사 자료를 분석한 결과, Cronbach's $\alpha$ 값이 0.5 이상의 값을 보여 신뢰도가 있다고 평가되었다.

\section{설문조사 및 자료 분석}

4-5학년 학급 중 각 학년별 무작위로 추출된 3개 학급에서 학부모의 사전 동의를 얻은 학급 전체 학생들을 대상으로 훈련된 조사원들의 진행을 통해 설문조사를 실시하였다. 설문조사 자료는 SPSS (ver. 18.0; SPSS Inc.)을 이용하여 분석하였으며, 모든 자료는 평균 \pm 표준편차 또 는 빈도 (백분율)로 표시하였다. 연속형 변수의 처리와 리커르트 평가 문항은 점수화하여 평 균과 표준편차를 구하였고, 교육 인지군과 비인지군 간의 차이에 대한 유의성 검증은 t-test 를 실시하였다. 하루 평균 당류 섭취량의 경우 당류 제품 섭취빈도조사 자료로부터 하루 평 균 섭취 빈도를 산출하고, 이를 예로 제시한 당류 식품 1 회 섭취량별 당 함량의 평균값을 곱하 여 계산하였다. 질적자료의 경우 빈도 분석을 통한 빈도와 백분위를 구하고, $\chi^{2}$ 검증을 실시 하였다. 각 군별 간식류의 선택에 있어 동일한 식품군 내에서 당분이 많이 함유된 제품의 섭 취 빈도와 상대적으로 당분이 적게 함유된 제품의 섭취 빈도 차이를 평가하기 위하여 paired t-test를 실시되었다. 또한, 당 관련 지식점수와 식행동점수의 상관성 분석을 위해 Pearson's correlation 분석을 실시하였고, 평균 하루 총 당 섭취량에 영향을 미치는 요인을 파악하기 위 해 단순선형회귀분석이 수행되었고, 모든 통계의 유의수준은 $\alpha=0.05$ 을 기준으로 하였다.

\section{결과}

\section{일반적 특성}

교육 인지군과 비인지군 사이의 일반적인 사항은 Table 1과 같이 성별 분포 및 평균 체질량지 수 (body mass index, BMI)는 당 교육 인지 여부에 따라 유의적인 차이를 보이지 않았다. 조사 대상자의 가족구성 형태를 보면 $94.0 \%$ 정도가 부모와 함께 거주하고 있었으며, $4.5 \%$ 는 편부 나 편모 가정이었고, $1.1 \%$ 는 부모 없이 조부모와 함께 살고 있는 것으로 나타났으나 당 교육 인지 여부에 따른 차이는 존재하지 않았다. 또한 당류 관련 교육을 수행한 대상자를 보면 영 
Table 1. General characteristics of subjects according to the sugar education recognition

\begin{tabular}{|c|c|c|c|c|}
\hline Characteristics & Total $(n=572)$ & Non-recognition group $(n=302)$ & Recognition group $(n=270)$ & Sig. \\
\hline Gender & & & & NS \\
\hline Men & $294(52.2)$ & $164(54.7)$ & $130(49.4)$ & \\
\hline Women & $269(47.8)$ & $136(45.3)$ & $133(50.6)$ & \\
\hline Body mass index & $18.7 \pm 3.4$ & $18.6 \pm 3.6$ & $18.7 \pm 3.1$ & NS \\
\hline Types of family & & & & NS \\
\hline Parents & $528(94.5)$ & $281(94.9)$ & 247 (93.9) & \\
\hline Single parent & $23(4.5)$ & $10(3.4)$ & $13(5.7)$ & \\
\hline Grandparents-grandchildren & $6(1.1)$ & $5(1.7)$ & $1(0.4)$ & \\
\hline Type of sugar education & & & & NS \\
\hline By dietitian & $333(58.2)$ & $182(60.3)$ & $151(55.9)$ & \\
\hline By teachers & $239(41.8)$ & $120(39.7)$ & $119(44.1)$ & \\
\hline
\end{tabular}

Values are expressed as number (\%) or mean \pm SD.

NS, not significantly.

양교사 $58.2 \%$, 교사 $41.8 \%$ 로 영양교사가 교육을 실시한 비율이 다소 높았으나, 교육 인지군 과 비인지군 사이에서 당류 관련 교육을 실시한 영양교사와 교사가 차지하는 비율은 두 군 간 에 유의적인 차이를 보이지 않았다.

\section{당 섭취 교육 인지 여부에 따른 영양지식과 식행동 비교}

당 섭취 교육 인지 여부에 따라 영양지식 점수를 비교한 결과는 Table 2와같이 총 11 점 만점 중 교육 인지군 10.08 점, 비인지군 10.02 점으로 당 섭취 교육 인지 여부에 상관없이 10점대의 점 수를 보여 두 군 간에 유의적인 차이를 보이지 않았다. 그러나 당 섭취 관련 이론적 지식 점수 는 교육 인지군 3.67점, 비인지군 3.55점으로 교육 인지군의 점수가 비인지군에 비해 유의적 으로 높았다 $(\mathrm{p}<0.05)$. 당을 적게 먹을 수 있는 바른 행동에 대한 지식 점수는 당 섭취 교육 인 지 여부에 따른 두 군 간에 유의적인 차이를 보이지 않았다. 당 관련 지식 중 가장 정답률이 낮 았던 문항은 천연식품 중 당 함량이 가장 높은 식품을 고르는 문제로 교육 인지군에서 $71.3 \%$, 비인지군에서 $66.3 \%$ 였으나, 두 군 간의 유의적 차이는 없었다. 반면 당 관련 지식 중 정답률 이 가장 높았던 문항은 가공식품 중 당 함량이 가장 높은 식품을 고르는 문제로 인지군과 비 인지군 각각 $100 \%$ 와 $99.3 \%$ 이었다.

Table 2. Sugar-related nutritional knowledge score according to sugar education recognition

\begin{tabular}{|c|c|c|c|c|}
\hline Questions & Total $(n=572)$ & Non-recognition group $(n=302)$ & Recognition group $(n=270)$ & Sig. \\
\hline \multicolumn{5}{|l|}{ Choose the most adequate answer } \\
\hline Which of the following taste is the sugar? & $0.98 \pm 0.14$ & $0.97 \pm 0.17$ & $0.99 \pm 0.09$ & $p<0.05$ \\
\hline Which of the processed foods has the most sugar? & $1.00 \pm 0.06$ & $0.99 \pm 0.08$ & $1.00 \pm 0.00$ & NS \\
\hline Sub-total scores & $3.60 \pm 0.56$ & $3.55 \pm 0.57$ & $3.67 \pm 0.52$ & $p<0.05$ \\
\hline \multicolumn{5}{|l|}{ True or false: It is good choice for low sugar intake } \\
\hline Eat tomato with sugars & $0.95 \pm 0.22$ & $0.96 \pm 0.20$ & $0.94 \pm 0.24$ & NS \\
\hline Eat frequently soda drinks rather than water if thirsty & $0.96 \pm 0.19$ & $0.97 \pm 0.16$ & $0.96 \pm 0.20$ & NS \\
\hline Eat chocolate or Banana milk rather than regular milk & $0.92 \pm 0.28$ & $0.94 \pm 0.24$ & $0.89 \pm 0.31$ & NS \\
\hline Eat vegetables or fruits rather than processed foods & $0.87 \pm 0.34$ & $0.87 \pm 0.34$ & $0.89 \pm 0.32$ & NS \\
\hline Do not eat too much food if not going to be fat & $0.90 \pm 0.29$ & $0.91 \pm 0.29$ & $0.90 \pm 0.30$ & NS \\
\hline Sub-total scores & $6.42 \pm 1.15$ & $6.46 \pm 1.04$ & $6.40 \pm 1.19$ & NS \\
\hline
\end{tabular}

Values are expressed as mean \pm SD.

NS, not significantly. 
Table 3. Sugar consumption related dietary behavior according to sugar education recognition

\begin{tabular}{|c|c|c|c|c|}
\hline Variables & Total $(n=572)$ & Non-recognition group $(n=302)$ & Recognition group $(n=270)$ & Sig. \\
\hline $\begin{array}{l}\text { Total score of dietary behavior for reducing sugar } \\
\text { consumption }\end{array}$ & $19.98 \pm 3.12$ & $19.83 \pm 3.07$ & $20.22 \pm 3.05$ & NS \\
\hline Do not eat ice cream frequently & $2.97 \pm 0.86$ & $2.92 \pm 0.88$ & $3.03 \pm 0.83$ & NS \\
\hline Do not eat candies frequently & $3.45 \pm 0.78$ & $3.46 \pm 0.76$ & $3.45 \pm 0.81$ & NS \\
\hline Do not eat chocolate frequently & $3.40 \pm 0.79$ & $3.35 \pm 0.79$ & $3.47 \pm 0.77$ & NS \\
\hline Do not consume soft drink (carbonated drink) often & $3.17 \pm 0.88$ & $3.14 \pm 0.86$ & $3.22 \pm 0.89$ & NS \\
\hline Do not consume bread with jam & $3.25 \pm 0.94$ & $3.25 \pm 0.94$ & $3.26 \pm 0.93$ & NS \\
\hline Do not consume fruit with sugar & $3.74 \pm 0.63$ & $3.72 \pm 0.67$ & $3.79 \pm 0.54$ & NS \\
\hline Checking sugar content in nutrition labeling before purchasing & $128(22.8)$ & $46(15.4)$ & $82(31.2)$ & $p<0.001$ \\
\hline Changing food choice after checking sugar content & $91(69.5)$ & $30(63.8)$ & $61(72.6)$ & NS \\
\hline \multicolumn{5}{|l|}{ Choice of beverage } \\
\hline Pure water & $509(90.4)$ & $271(90.6)$ & $238(90.2)$ & NS \\
\hline Soft drink (carbonated drink) & $134(23.8)$ & $75(25.1)$ & $59(22.4)$ & NS \\
\hline Fruit or vegetable Juice & $128(22.8)$ & $65(21.8)$ & $63(23.8)$ & NS \\
\hline Milk or fermented milk & $169(30.0)$ & $95(31.8)$ & $74(28.0)$ & NS \\
\hline Smoothie & $51(9.1)$ & $28(9.4)$ & $23(8.7)$ & NS \\
\hline \multicolumn{5}{|l|}{ Frequency of purchasing snack by oneself } \\
\hline Do not purchase snack & $258(45.2)$ & $140(46.4)$ & $118(43.9)$ & \\
\hline 1-2 times/week & $243(42.6)$ & $124(41.1)$ & $119(44.2)$ & \\
\hline 3-4 times/week & $44(7.7)$ & $24(7.9)$ & $20(7.4)$ & NS \\
\hline 5-6 times/week & $9(1.6)$ & $6(2.0)$ & $3(1.1)$ & \\
\hline$\geq 7$ times/week & $17(3.0)$ & $8(2.6)$ & $9(3.3)$ & \\
\hline
\end{tabular}

Values are expressed as number (\%) or mean \pm SD.

NS, not significantly.

당 섭취와 관련된 식행동으로 당 섭취를 줄이기 위한 노력 정도에 따라 ‘항상 노력한다’ 4점, '가끔 노력한다’ 3점, ‘노력하지 않는다’ 2점, ‘전혀 노력하지 않는다' 1점을 부여한 후 교육 인 지군과 비인지군의 당 관련 식행동 점수를 비교한 결과는 Table 3과 같다. 당 섭취를 줄이기 위한 식행동 총 점수를 보면 교육 인지군 20.22점, 비인지군 19.83점으로 교육 인지군이 다소 높았으나 통계적으로 유의적인 차이를 보이지 않았고, 당류 섭취를 줄이기 위한 식행동 관 련 각 문항별 점수 역시 당 섭취 교육 인지 여부에 따른 유의적인 차이를 보이지 않았다. 그 러나 가공식품 구매 전 영양표시에서 당류 함량을 확인한다고 응답한 비율은 교육 비인지 군 $(15.4 \%)$ 에 비해 인지군 $(31.2 \%)$ 에서 유의적으로 높았다. 영양표시의 당 함량을 확인한다 고 응답한 대상자를 중심으로 당 함량 확인 후 식품 선택에 영향을 미치는 지를 조사한 결과 영양표시 확인 후 식품 선택을 변경하였다고 응답한 비율은 교육 인지군 $72.6 \%$, 비인지군 $63.8 \%$ 로 교육인지군이 비인지군에 비해 다소 높은 수준이었으나 통계적으로 유의적인 차 이는 아니었다.

당 섭취 교육 인지 여부에 따라 갈증 시 주로 섭취하는 음료를 보면 교육 인지군과 비인지군 모두 생수나 보리차 등 당류를 함유하고 있지 않은 음료를 섭취한 비율이 각각 $90 \%$ 이상으 로 가장 높았고, 그 다음으로 우유와 발효유류, 탄산음료 및 스무디류, 과일 및 야채주스류의 순으로 나타나 갈증 시 당류를 함유하고 있는 음료보다는 당류를 함유하고 있는 않은 음료 를 주로 섭취하는 것으로 나타났고, 당 섭취 교육 인지 여부에 따른 차이는 존재하지 않았다.

학교 방과 후 또는 학원을 마친 후 집으로 오는 길에 직접 간식을 사 먹는 비율을 보면 전체 대 상자의 $54.8 \%$ 는 주 1 회 이상 직접 간식을 사 먹는다고 응답하였고, 당 교육 인지 여부에 따라 교육인지군의 경우 $56.1 \%$, 비인지군 53.6\%가 주 1 회 이상 간식을 구입한다고 응답하고 있으 며, 두 군 모두 주 1-2회 정도 간식을 구입한다고 응답한 비율이 가장 높았다. 자료를 제시하 
지는 않았으나 주 1 회 이상 간식을 사 먹는 아동들의 $31.7 \%$ 는 편의점에서, $20.5 \%$ 는 분식집에 서, $2.9 \%$ 는 문구점에서 사 먹는다고 응답하여 주로 학교나 학원 주변의 편의점, 분식점 및 문 구점을 이용하는 것으로 나타나 방과 후 간식 구입 빈도 및 이용 장소는 당 섭취 교육 인지 여 부에 따른 차이를 보이지 않았다.

Table 4는 당 섭취 교육 인지 여부에 따라 당류의 급원 식품군별로 주당 평균 섭취 빈도를 나 타낸 것으로 교육 인지군의 경우 캔디, 껌, 젤리 등의 당류 식품 선택 시 무가당 껌이나 사탕을 섭취하는 빈도가 0.92 회/주로 비인지군 0.52 회/주에 비해 유의적으로 높았고 ( $<$ < 0.05), 과일 류 섭취에서 생과일의 주당 섭취 빈도 역시 교육 인지군이 5.54 회/주로 비인지군 4.76 회/주에

Table 4. Average sugar intake frequency according to sugar education recognition (times/week)

\begin{tabular}{|c|c|c|c|c|c|}
\hline \multicolumn{2}{|l|}{ Food item } & $\begin{array}{c}\text { Total } \\
(n=572)\end{array}$ & $\begin{array}{l}\text { Non-recognition } \\
\text { group }(\mathrm{n}=302)\end{array}$ & $\begin{array}{c}\text { Recognition } \\
\text { group }(n=270)\end{array}$ & Sig. \\
\hline \multicolumn{6}{|l|}{ Breads } \\
\hline Sweet & Donut, cream bread, choco-pie, castella, etc. & $0.87 \pm 1.39$ & $1.05 \pm 1.82$ & $0.84 \pm 1.31$ & NS \\
\hline Unsweet & Bread, roll bread, baguette, bagel, etc. & $1.55 \pm 2.10$ & $1.20 \pm 1.54$ & $1.61 \pm 2.19$ & NS \\
\hline \multicolumn{2}{|c|}{ Difference in frequency between sweet and unsweet (paired t-test) } & 0.000 & 0.573 & 0.000 & \\
\hline \multicolumn{6}{|l|}{ Ice creams } \\
\hline Hard ice cream & Cone ice cream, hard ice cream, etc. & $1.91 \pm 2.33$ & $2.23 \pm 2.11$ & $1.86 \pm 2.37$ & NS \\
\hline Bingsoo & Red bean bingsoo, milk bingsoo, etc. & $0.45 \pm 1.16$ & $0.48 \pm 1.10$ & $0.44 \pm 1.17$ & NS \\
\hline \multicolumn{2}{|c|}{ Difference in frequency between hard ice cream and bingsoo (paired t-test) } & 0.000 & 0.000 & 0.000 & \\
\hline \multicolumn{6}{|l|}{ Soft soda drinks } \\
\hline Sweet & Cider, cola, fanta, etc. & $1.21 \pm 1.89$ & $1.10 \pm 1.52$ & $1.22 \pm 1.95$ & NS \\
\hline Sugar free soda & Zero-calorie cola, diet cola, etc. & $0.30 \pm 1.17$ & $0.24 \pm 1.13$ & $0.31 \pm 1.18$ & NS \\
\hline \multicolumn{2}{|c|}{ Difference in frequency between sweet and sugar free soda (paired t-test) } & 0.000 & 0.002 & 0.000 & \\
\hline \multicolumn{6}{|c|}{ Fruit and vegetable beverages } \\
\hline Sweetened juice & Caprisun, juice-containing drink, vegetable juice, etc. & $0.97 \pm 1.92$ & $1.06 \pm 2.41$ & $0.97 \pm 1.84$ & NS \\
\hline Unsweetened juice & $100 \%$ juice, sugar-free raw fruit juice, v8, etc. & $1.15 \pm 1.76$ & $0.99 \pm 1.48$ & $1.18 \pm 1.80$ & NS \\
\hline \multicolumn{2}{|c|}{ Difference in frequency between sweetened and unsweetened juice (paired t-test) } & 0.092 & 0.851 & 0.053 & \\
\hline \multicolumn{6}{|c|}{ Candy, gum, jelly, caramel, chocolate } \\
\hline Sweet & Chupa-chups, gum, maizhu, caramel, chocolate, etc. & $1.33 \pm 2.81$ & $2.22 \pm 2.78$ & $1.20 \pm 2.81$ & NS \\
\hline Unsweet & Xylitol gum, ricola, mint, anytime, etc. & $0.86 \pm 1.71$ & $0.52 \pm 0.84$ & $0.92 \pm 1.81$ & $\mathrm{p}<0.05$ \\
\hline \multicolumn{2}{|c|}{ Difference in frequency between sweet and unsweet (paired t-test) } & 0.000 & 0.000 & 0.000 & \\
\hline \multicolumn{6}{|l|}{ Milk and soy milk } \\
\hline White milk & Packed milk, bottled milk, sterilized milk, etc. & $4.65 \pm 3.99$ & $4.01 \pm 2.53$ & $4.76 \pm 4.17$ & NS \\
\hline Processed milk & Banana milk, strawberry milk, chocolate milk, etc. & $0.84 \pm 1.69$ & $0.73 \pm 1.62$ & $0.86 \pm 1.71$ & NS \\
\hline Soy milk & Vegemil, black bean soy milk, nutribean, etc. & $0.94 \pm 2.27$ & $0.66 \pm 2.43$ & $0.99 \pm 2.25$ & NS \\
\hline \multicolumn{2}{|c|}{ Difference in frequency between white milk (soy milk) and processed milk (paired t-test) } & 0.000 & 0.000 & 0.000 & \\
\hline \multicolumn{6}{|l|}{ Fermented milk } \\
\hline Sweet & Strawberry flavor yogurt liquid/curd, etc. & $0.75 \pm 1.71$ & $0.76 \pm 1.64$ & $0.73 \pm 1.71$ & NS \\
\hline Unsweet & Plain yogurt liquid/curd & $1.21 \pm 1.73$ & $1.00 \pm 1.43$ & $1.24 \pm 1.78$ & NS \\
\hline \multicolumn{2}{|c|}{ Difference in frequency between sweet and unsweet fermented milk (paired t-test) } & 0.000 & 0.334 & 0.000 & \\
\hline \multicolumn{6}{|l|}{ Biscuits } \\
\hline Sweet & Buttering, chocolate chips, chocoheim, custard, etc. & $0.92 \pm 1.55$ & $0.88 \pm 1.56$ & $0.93 \pm 1.56$ & NS \\
\hline Unsweet & Ace, charm cracker, etc. & $0.72 \pm 1.73$ & $0.66 \pm 1.52$ & $0.72 \pm 1.77$ & NS \\
\hline \multicolumn{2}{|c|}{ Difference in frequency between sweet and unsweet (paired t-test) } & 0.048 & 0.326 & 0.068 & \\
\hline \multicolumn{6}{|l|}{ Snacks } \\
\hline Sweet & Jjanggu, joripong, honey kkwabaegi, home run ball, etc. & $1.17 \pm 1.70$ & $1.16 \pm 1.67$ & $1.18 \pm 1.76$ & NS \\
\hline Unsweet & Potato chips, shrimp chips, onion rings, etc. & $1.23 \pm 1.80$ & $1.26 \pm 1.85$ & $1.32 \pm 1.75$ & NS \\
\hline \multicolumn{2}{|c|}{ Difference in frequency between sweet and unsweet (paired t-test) } & 0.110 & 0.302 & 0.200 & \\
\hline \multicolumn{6}{|l|}{ Fruits } \\
\hline Raw fruit & Apple, grape, pear, peach, strawberry, etc. & $5.13 \pm 4.06$ & $4.76 \pm 3.78$ & $5.54 \pm 4.31$ & $\mathrm{p}<0.05$ \\
\hline Processed fruit & Raisins, dried mangoes, canned peaches, etc. & $0.57 \pm 1.71$ & $0.46 \pm 1.31$ & $0.70 \pm 2.08$ & NS \\
\hline \multicolumn{2}{|c|}{ Difference in frequency between raw and processed fruit (paired t-test) } & 0.000 & 0.000 & 0.000 & \\
\hline
\end{tabular}

Values are expressed as mean \pm SD.

NS, not significantly. 
비해 유의적으로 높았다 ( $\mathrm{p}<0.05)$. 이외 식품군의 경우 영양교육 인지 여부에 따라 주당 섭취 빈도에 유의적인 차이를 보이지 않았다. 각 식품군별로 당류 함량이 높은 식품과 상대적으로 당류 함량이 낮은 식품 사이의 주당 섭취빈도 차이를 보면, 빵류와 우유, 발효유, 과일류의 섭 취 시 상대적으로 당 함량이 낮은 식품을 섭취하는 빈도가 높은 반면, 아이스크림류, 탄산음 료, 캔디, 껌 및 젤리류, 비스켓류의 경우 무가당이나 당 함량이 적은 식품보다는 단맛이 나거 나 당 함량이 높은 가당 식품의 섭취빈도가 유의적으로 높았다. 당 교육 인지 여부에 따른 차 이를 보면, 빵류와 발효유의 경우 교육 인지군에서는 달지 않은 빵과 무가당 발효유를 선택 하는 빈도가 유의적으로 높았던 반면 ( $\mathrm{p}<0.001)$, 교육 비인지군의 경우 유의적인 차이가 나 타나지 않았다.

Table 5는 당류의 급원 식품군별 섭취 빈도와 각 식품군별 대표 식품들의 평균 당 함량을 기 준으로 하루 평균 당류 섭취량을 산출한 결과를 제시한 것이다. 하루 단위 총 당류 섭취량을 산출한 결과 전체대상자의 경우 하루 $39.02 \mathrm{~g} / \mathrm{day}$ 의 당류를 섭취하였고, 교육 인지군의 경우 $41.47 \mathrm{~g} / \mathrm{day}$, 비인지군의 경우 $37.17 \mathrm{~g} / \mathrm{day}$ 의 당류를 섭취하는 것으로 나타나 교육 인지군에 비 해 비인지군에서 당 섭취량이 $4 \mathrm{~g}$ 정도 낮았으나 통계적으로 유의적인 차이는 아니었다. 각 식품군별 당류 섭취량 중 하루 총 당 섭취량에 대한 기여도가 높은 식품군은 과일·채소, 음료 류로 가당 주스와 무가당 주스를 통해 하루 $11 \mathrm{~g}$ 정도 섭취하는 것으로 나타났고, 가당 주스에 비해 무가당 주스의 섭취 빈도가 높았음에도 불구하고 하루 평균 당류 섭취량은 가당 주스 (3.21 $\pm 4.41 \mathrm{~g} / \mathrm{day})$ 보다 무가당 주스로부터 섭취하는 양 $(7.74 \pm 4.90 \mathrm{~g} / \mathrm{day})$ 이 오히려 더 유의적 으로 높았다. 실제 ‘무가당’이라고 표시된 제품 1 회 분량의 평균 당류 함량은 $21.3 \mathrm{~g}$ 으로 넥타 등 가당음료의 평균 당류 함량은 $16.0 \mathrm{~g}$ 으로 무가당제품의 경우 첨가당을 쓰지 않았음에도 불 구하고 과일 함량이 높아 당류 함량 자체가 높았고, 이로부터 기인하는 당류 섭취량 역시 높 아졌다고 볼 수 있다. 그러나 과일류를 통한 당류 섭취량은 당 교육 인지 여부에 따른 두 군간 에 유의적인 차이를 보이지 않았다. 발효유류의 경우 교육 인지군에서 무가당 발효유의 섭취 빈도가 높았으나 실제 가당제품이나 무가당제품으로부터의 당류 섭취량은 유의적인 차이 가 없었다. 당 교육 인지 여부에 따른 당류 섭취량을 비교해 보면, 교육 인지군이 비인지군에 비해 달지 않은 당류, 흰우우류, 생과일을 통한 당류 섭취량이 유의적으로 높았다 ( $\mathrm{p}<0.05)$.

당 섭취 관련 총지식점수와 식행동 사이의 관련성 파악을 위해 상관분석을 실시한 결과는 Table 6과 같이 총지식점수가 높을수록 식행동점수가 높고 $(\mathrm{r}=0.215, \mathrm{p}<0.001)$, 방과 후 간식 구입 빈도 $(\mathrm{r}=-0.142, \mathrm{p}<0.01)$ 및 하루 평균 당류 섭취량은 낮아졌다 $(\mathrm{r}=-0.163, \mathrm{p}<0.001)$. 당 섭취 관련 지식 점수와의 상관성이 가장 크게 나타난 개별 식행동 항목은 '탄산음료를 자 주 먹지 않는다’이었고, 가장 낮은 상관성을 보인 항목은 '사탕을 자주 먹지 않는다'이었다.

또한, 영양지식와 식행동 간의 상관성은 당 섭취 교육 인지 여부에 따라 다르게 나타났다. 즉, 당 섭취 교육 인지군의 경우 당류 관련 총지식점수는 아이스크림 $(\mathrm{r}=0.140, \mathrm{p}<0.05)$ 이나 초 콜릿 $(r=0.137, \mathrm{p}<0.05)$, 탄산음료를 자주 먹지 않기 위한 노력 $(\mathrm{r}=0.267, \mathrm{p}<0.01)$ 을 포함한 전 체 식행동 점수 $(\mathrm{r}=0.211, \mathrm{p}<0.01)$ 와 유의적인 양의 상관관계를, 방과 후 간식 구입 빈도와는 유의적인 음의 상관관계 $(\mathrm{r}=-0.148, \mathrm{p}<0.05)$ 를 보였고, 비인지군에 비해 교육 인지군에서 상 관성이 더 높았다. 반면 비인지군의 경우 ‘빵을 먹을 때 쨈을 많이 발라 먹지 않는다'거나 '과 일을 먹을 때 설탕에 찍어 먹지 않는다와 같은 첨가당 사용 및 하루 평균 당류섭취량 사이에 서 총지식점수와 유의적인 양의 상관성을 보였다 $(\mathrm{p}<0.05)$. 
Table 5. Average sugar intake per day according to sugar education recognition (g/day)

\begin{tabular}{|c|c|c|c|c|c|}
\hline \multicolumn{2}{|l|}{ Food item } & Total $(n=572)$ & $\begin{array}{l}\text { Non-recognition } \\
\text { group }(n=302)\end{array}$ & $\begin{array}{c}\text { Recognition } \\
\text { group }(n=270)\end{array}$ & Sig. \\
\hline \multicolumn{6}{|l|}{ Breads } \\
\hline Sweet & Donut, cream bread, choco-pie, castella, etc. & $2.00 \pm 3.37$ & $1.96 \pm 3.49$ & $2.04 \pm 3.24$ & NS \\
\hline Unsweet & Bread, roll bread, baguette, bagel, etc. & $0.72 \pm 0.94$ & $0.62 \pm 0.73$ & $0.83 \pm 1.12$ & $\mathrm{p}<0.01$ \\
\hline \multicolumn{2}{|c|}{ Difference in frequency between sweet and unsweet (paired t-test) } & 0.000 & 0.000 & 0.000 & \\
\hline \multicolumn{6}{|l|}{ Ice creams } \\
\hline Hard ice cream & Cone ice cream, hard ice cream, etc. & $4.98 \pm 6.15$ & $4.92 \pm 5.54$ & $5.11 \pm 6.83$ & NS \\
\hline Bingsoo & Red bean bingsoo, milk bingsoo, etc. & $2.43 \pm 6.89$ & $2.18 \pm 6.84$ & $2.67 \pm 7.01$ & NS \\
\hline \multicolumn{2}{|c|}{ Difference in frequency between hard ice cream and bingsoo (paired t-test) } & 0.000 & 0.000 & 0.000 & \\
\hline \multicolumn{6}{|c|}{ Soft soda drinks } \\
\hline Sweet & Cider, cola, fanta, etc. & $4.27 \pm 6.09$ & $4.09 \pm 5.17$ & $4.46 \pm 7.02$ & NS \\
\hline Sugar free soda & Zero-calorie cola, diet cola, etc. & $0.00 \pm 0.00$ & $0.00 \pm 0.00$ & $0.00 \pm 0.00$ & NS \\
\hline \multicolumn{2}{|c|}{ Difference in frequency between sweet and sugar free soda (paired t-test) } & 0.000 & 0.000 & 0.000 & \\
\hline \multicolumn{6}{|c|}{ Fruit and vegetable beverages } \\
\hline Sweetened juice & Caprisun, juice-containing drink, vegetable juice, etc. & $3.21 \pm 4.41$ & $2.60 \pm 2.98$ & $3.86 \pm 5.41$ & NS \\
\hline Unsweetened juice & $100 \%$ juice, sugar-free raw fruit juice, v8, etc. & $7.74 \pm 4.90$ & $7.22 \pm 4.16$ & $8.26 \pm 5.52$ & NS \\
\hline \multicolumn{2}{|c|}{ Difference in frequency between sweetened and unsweetened juice (paired t-test) } & 0.000 & 0.000 & 0.000 & \\
\hline \multicolumn{6}{|c|}{ Candy, gum, jelly, caramel, chocolate } \\
\hline Sweet & Chupa-chups, gum, maizhu, caramel, chocolate, etc. & $4.17 \pm 6.07$ & $4.29 \pm 6.34$ & $4.10 \pm 5.82$ & NS \\
\hline Unsweet & Xylitol gum, ricola, mint, anytime, etc. & $0.00 \pm 0.00$ & $0.00 \pm 0.00$ & $0.00 \pm 0.00$ & NS \\
\hline \multicolumn{2}{|c|}{ Difference in frequency between sweet and unsweet (paired t-test) } & 0.000 & 0.000 & 0.000 & \\
\hline \multicolumn{6}{|l|}{ Milk and soy milk } \\
\hline White milk & Packed milk, bottled milk, sterilized milk, etc. & $7.49 \pm 4.87$ & $6.86 \pm 4.46$ & $8.26 \pm 5.21$ & $p<0.01$ \\
\hline Processed milk & Banana milk, strawberry milk, chocolate milk, etc. & $2.41 \pm 4.88$ & $2.10 \pm 4.59$ & $2.79 \pm 5.21$ & NS \\
\hline Soy milk & Vegemil, black bean soy milk, nutribean, etc. & $0.94 \pm 2.24$ & $0.79 \pm 1.99$ & $1.12 \pm 2.5$ & NS \\
\hline \multicolumn{2}{|c|}{ Difference in frequency between white milk (soy milk) and processed milk (paired t-test) } & 0.000 & 0.000 & 0.000 & \\
\hline \multicolumn{6}{|l|}{ Fermented milk } \\
\hline Sweet & Strawberry flavor yogurt liquid/curd, etc. & $1.40 \pm 3.33$ & $1.25 \pm 3.13$ & $1.55 \pm 3.52$ & NS \\
\hline Unsweet & Plain yogurt liquid/curd & $1.18 \pm 1.78$ & $1.14 \pm 1.81$ & $1.23 \pm 1.77$ & NS \\
\hline \multicolumn{2}{|c|}{ Difference in frequency between sweet and unsweet fermented milk (paired t-test) } & 0.125 & 0.571 & 0.149 & \\
\hline \multicolumn{6}{|l|}{ Biscuits } \\
\hline Sweet & Buttering, chocolate chips, chocoheim, custard, etc. & $1.06 \pm 1.93$ & $1.09 \pm 2.12$ & $1.03 \pm 1.72$ & NS \\
\hline Unsweet & Ace, charm cracker, etc. & $0.18 \pm 0.41$ & $0.16 \pm 0.32$ & $0.20 \pm 0.50$ & NS \\
\hline \multicolumn{2}{|c|}{ Difference in frequency between sweet and unsweet (paired t-test) } & 0.000 & 0.000 & 0.000 & \\
\hline \multicolumn{6}{|l|}{ Snacks } \\
\hline Sweet & Jjanggu, joripong, honey kkwabaegi, home run ball, etc. & $1.59 \pm 2.32$ & $1.58 \pm 2.26$ & $1.60 \pm 2.39$ & NS \\
\hline Unsweet & Potato chips, shrimp chips, onion rings, etc. & $0.27 \pm 0.39$ & $0.27 \pm 0.40$ & $0.28 \pm 0.38$ & NS \\
\hline \multicolumn{2}{|c|}{ Difference in frequency between sweet and unsweet (paired t-test) } & 0.000 & 0.000 & 0.000 & \\
\hline \multicolumn{6}{|l|}{ Fruits } \\
\hline Raw fruit & Apple, grape, pear, peach, strawberry, etc. & $3.01 \pm 2.37$ & $2.80 \pm 2.21$ & $3.24 \pm 2.52$ & $p<0.05$ \\
\hline Processed fruit & Raisins, dried mangoes, canned peaches, etc. & $0.41 \pm 1.22$ & $0.33 \pm 0.93$ & $0.50 \pm 1.49$ & NS \\
\hline \multicolumn{2}{|c|}{ Difference in frequency between raw and processed fruit (paired t-test) } & 0.000 & 0.000 & 0.000 & \\
\hline \multicolumn{2}{|c|}{ Average total sugar intake per day (g/day) } & $39.02 \pm 29.21$ & $37.17 \pm 28.90$ & $41.47 \pm 29.65$ & NS \\
\hline
\end{tabular}

Values are expressed as mean \pm SD.

NS, not significantly.

Table 7은 하루 평균 총 당류 섭취량에 영향을 미치는 요인을 파악하기 위해 회귀분석을 실시 한 결과를 제시한 것이다. 전체 조사대상자에서 가장 큰 관련성을 보인 요인은 학교나 학원 에서 집으로 오는 길에 간식을 구입하는 빈도로 구입 빈도가 높을수록 당류 섭취량이 높게 나타났다. 이외 식행동 점수와 당류 섭취량은 음의 관련성이 있는 것으로 나타났다. 또 성별 역시 당류 섭취량에 영향을 미치는 요인으로 분석되었다. 당 섭취 교육 인지 여부에 따라 당 류 섭취량에 영향을 미치는 요인을 보면, 교육 인지군의 경우 영양교사의 교육 여부와 총 식 행동 점수는 음의 관련성을 보여 총 당류 섭취량을 감소시키는 요인이었으나, 당 관련 총 지 식 점수, 간식구입빈도와는 양의 상관성을 보여 하루 총 당류 섭취량을 증가시키는 요인이었 다. 비인지군의 경우 성별과 총 식행동 점수는 음의 관련성을, 간식구입 빈도와는 양의 관련 
Table 6. Correlation coefficient between sugar-related knowledge score and dietary behavior score

\begin{tabular}{|c|c|c|c|}
\hline Variables & Total $(n=572)$ & Non-recognition group $(n=302)$ & Recognition group $(n=270)$ \\
\hline Total dietary behavior score & $0.215^{\star \star \star}$ & $0.140^{*}$ & $0.211^{\star *}$ \\
\hline Do not eat ice cream frequently & $0.145^{* *}$ & $0.119^{*}$ & $0.140^{*}$ \\
\hline Do not eat candies frequently & $0.089^{*}$ & $0.015^{\mathrm{NS}}$ & $0.107^{\mathrm{NS}}$ \\
\hline Do not eat chocolate frequently & $0.109^{*}$ & $0.034^{\mathrm{NS}}$ & $0.137^{*}$ \\
\hline Do not consume soft drink (carbonated drink) often & $0.182^{\star *}$ & $0.047^{\mathrm{NS}}$ & $0.267^{\star * *}$ \\
\hline Do not consume bread with jam & $0.128^{* *}$ & $0.172^{* *}$ & $0.030^{\mathrm{NS}}$ \\
\hline Do not consume fruit with sugar & $0.173^{* * *}$ & $0.128^{*}$ & 0.121 \\
\hline Checking sugar content in nutrition labeling before purchasing & $-0.074^{\mathrm{NS}}$ & $-0.053^{N S}$ & $-0.072^{N S}$ \\
\hline Frequency of snack purchases after school & $-0.142^{* *}$ & $-0.137^{\star}$ & $-0.148^{*}$ \\
\hline Average sugar intake per day & $-0.163^{* * *}$ & $-0.215^{* * *}$ & $-0.139^{*}$ \\
\hline
\end{tabular}

NS, not significantly.

${ }^{*} p<0.05,{ }^{* *} p<0.01,{ }^{* * *} p<0.001$.

Table 7. Regression analysis of factors affecting total sugar intake per day

\begin{tabular}{|c|c|c|c|c|c|c|c|c|c|}
\hline \multirow[t]{2}{*}{ Variables } & \multicolumn{3}{|c|}{ Total $(n=572)$} & \multicolumn{3}{|c|}{ Non-recognition group $(n=302)$} & \multicolumn{3}{|c|}{ Recognition group $(n=270)$} \\
\hline & $\beta$ & $\mathrm{t}$ & Sig. & $\beta$ & $\mathrm{t}$ & Sig. & $\beta$ & $\mathrm{t}$ & Sig. \\
\hline Sugar education recognition & 0.081 & 1.838 & 0.067 & & & & & & \\
\hline Gender & -0.112 & -2.559 & 0.011 & -0.144 & -2.501 & 0.013 & -0.041 & -0.619 & 0.537 \\
\hline Age & 0.024 & 0.520 & 0.603 & 0.074 & 1.189 & 0.236 & -0.084 & -1.256 & 0.211 \\
\hline Body mass index & -0.031 & -0.684 & 0.494 & -0.065 & -1.053 & 0.294 & -0.001 & -0.021 & 0.983 \\
\hline Education of nutrition teachers & -0.036 & -0.800 & 0.424 & 0.018 & 0.304 & 0.762 & -0.156 & -2.358 & 0.020 \\
\hline Total sugar-related knowledge score & 0.053 & 1.214 & 0.225 & 0.003 & 0.049 & 0.961 & 0.129 & 1.977 & 0.050 \\
\hline Total dietary behavior score & -0.278 & -3.083 & 0.000 & -0.293 & -4.907 & 0.000 & -0.254 & -3.586 & 0.000 \\
\hline $\begin{array}{l}\text { Checking sugar content in nutrition labeling } \\
\text { before purchasing }\end{array}$ & 0.081 & 1.838 & 0.067 & 0.000 & 0.005 & 0.996 & 0.086 & 1.271 & 0.206 \\
\hline Frequency of snack purchases after school & 0.291 & 6.463 & 0.000 & 0.270 & 4.566 & 0.000 & 0.314 & 4.485 & 0.000 \\
\hline Significance & \multicolumn{3}{|c|}{$\mathrm{R}^{2}=0.228, \mathrm{p}<0.001$} & \multicolumn{3}{|c|}{$\mathrm{R}^{2}=0.206, \mathrm{p}<0.001$} & \multicolumn{3}{|c|}{$\mathrm{R}^{2}=0.241, \mathrm{p}<0.001$} \\
\hline
\end{tabular}

성을 보였을 뿐 교육 인지군과 같이 영양교사 교육 여부 및 당류 관련 총 지식 점수 사이에서 유의적인 관련성은 존재하지 않았다.

\section{고찰}

본 연구는 초등학교의 당 섭취에 대한 영양교육이 관련 식행동에 어떠한 영향을 미치는지를 평가하기 위하여 당 섭취에 관한 영양지식과 영양 태도, 식행동 및 당류 식품의 섭취 빈도와 당 섭취량을 조사하고, 당 교육 인지군과 비인지군으로 나누어 영양지식과 식행동에 어떠한 차이가 있는지를 분석함으로써 실제 초등학생들의 당류 섭취에 영향을 미치는 요인을 평가 하고자 하였다.

본 연구 결과, 조사대상자인 아동들은 학교 교육을 통해 당류 섭취에 대한 교육을 받았음에 도 불구하고 교육을 받았다고 인지하는 경우가 전체의 $46.6 \%$ 였고, 인지하지 못하는 경우가 전체의 $50.2 \%$ 로 나타났다. 교육을 받았다고 인지한 교육 인지군을 대상으로 당 섭취 영양교 육을 어디에서 받았는지를 질문했을 때 $84.4 \%$ 는 학교에서 영양교육을 받았다고 응답하였으 며, $13.7 \%$ 는 학교 이외의 장소에서 영양교육을 받았다고 응답하였다. 학교 이외의 장소에서 영양교육을 받았다고 응답한 아동들 중 $19 \%$ 는 집에서, 나머지는 지역아동센터, 병원, TV에 서 각 $17 \%$ 씩 골고루 분포하였다. 아동들이 인지하고 있는 당 교육 내용은 당에 대한 이론 교 육이 전체 $66.7 \%$ 로 가장 높았고, 다음은 단음식을 적게 먹는 실천 방법에 대한 교육으로 영양 
표시에서 당 함량 찾기, 당이 적은 간식 만들기 및 단맛 선호도 측정과 같은 실습교육을 받은 것으로 인지하였다 (자료 제시하지 않음).

당 교육을 받았음을 인지하는 아동들의 경우 당 관련 이론 지식 점수 $(3.67 \pm 0.52$ 점)가 비인지 군 $(3.55 \pm 0.57$ 점)에 비해 유의적으로 더 높았으나 $(\mathrm{p}<0.05)$, 당류 섭취 행동 관련 지식점수 및 실제 당류 섭취를 줄이기 위한 식행동에는 유의적인 차이가 없었다. 그럼에도 불구하고 당 교육 인지 아동의 경우 영양표시를 확인하는 비율이 유의적으로 더 높았고 (인지군 $31.2 \%$ vs 비인지군 $15.4 \%, \mathrm{p}<0.001$ ), 실제 당류 식품의 선택에 있어 무가당 껌이나 사탕 및 생과일 섭 취 빈도가 비인지군에 비해 높았으며, 교육 인지군에서만 빵류와 발효유류 섭취에 있어 당 류가 적게 함유한 식품의 선택 빈도가 당분을 많이 함유한 식품의 선택 빈도에 비해 유의적 으로 높게 나타났을 뿐만 아니라 흰우유 및 생과일과 같은 천연당의 섭취량이 높았다. 식품 선택 빈도나 당류 섭취량의 이러한 차이는 교육 비인지군에서는 나타나지 않았다. 영양지식 의 향상은 실제 식생활의 긍정적인 변화를 유도하고 올바른 식행동을 선택하는 도구로써 의 미가 있다. 영양교육에 적용되는 사회심리학적 이론들 중 합리적 행동 이론에 따르면 인간 은 합리적이며 이를 위해 자신이 이용할 수 있는 정보를 사용한다는 가정에 토대를 두고 있 다 [17]. 또 학습이란 지식으로부터 지속적으로 재창조될 때 의미가 있으며 구체적 경험을 통 해 실제에 적용할 수 있게 되므로 이러한 특징들을 잘 반영한 영양교육을 통해 식행동의 변 화를 확산시킬 수 있다고 했다 [17]. 본 연구 결과 역시 당류 섭취 교육에 대한 효과는 당 관련 이론적 지식을 향상시켰고, 비록 당류 섭취 관련 행동 지식 점수나 식행동 개선은 관찰되지 않았으나 실제 식품의 선택에는 긍정적인 영향을 미쳐 당 관련 지식 점수는 식행동점수와 양 의 상관관계를, 방과 후 간식 구입 빈도나 하루 평균 당류 섭취량과 음의 상관관계를 보였다.

영양교육을 통한 영양지식 향상은 비교적 단기적인 효과라고 할 수 있으며, 일회성의 단편적 교육이 아닌 체계적이고 단계적 교육을 실시할 때 비로소 식생활 태도 및 식행동의 변화를 유 도할 수 있는 것으로 알려져 있다. 동두천 지역의 초등학교 4학년을 대상으로 한 연구에서 영 양사에 의해 1 회 40 분씩 총 5 회에 걸친 영양교육 실시 후 지식 점수와 함께 식행동의 변화가 관찰되었으며, 열량 포함 일부 영양소들의 영양밀도 및 뢰러지수가 유의적으로 향상된 것으 로 보고하고 있으며 [18], 경기지역의 초등학교 1-4학년 학생들 중 편식 하는 아동들을 대상 으로 주 1 회당 약 30 분씩 학년별 특성을 고려하여 총 8 회에 걸친 영양교육 실시 후 비교육군 에 비해 교육군에서 아동의 영양 지식 점수, 식생활 태도 및 식습관이 향상된 것으로 보고하 였다 [19]. 또한, 초등학생에 적용 가능한 당 교육 프로그램 개발을 위해 수행된 연구에서 초 등학교 재량 교육 시간을 활용한 17 차시에 걸친 당 중심의 영양교육 프로그램을 수행 한 결과 영양지식 점수 및 식행동 점수가 향상되었으며, 가장 흥미도와 만족도가 높았던 활동은 건강 십자퍼즐과 건강 빙고게임 등 게임이나 역할극과 같이 직접 참여 활동이 가능한 차시로 나타 난 반면, 영양소의 종류, 당의 의미 등 기본적인 개념 및 원리 중심의 차시는 흥미도와 만족도 가 가장 낮았다 [20]. 본 연구에서 영양교육 인지군이 받은 영양교육의 주제로 가장 응답 빈 도가 높은 항목은 ‘당에 대하여'와 '단 음식을 적게 먹는 실천법'으로 당 섭취 관련 교육이 실 습 위주의 교육 보다는 주로 이론 교육이 더 많은 비중을 차지했음을 알 수 있었고, 이론 중심 의 영양교육이 1 년이라는 시간이 지난 후 영양교육을 받았다는 사실을 인지하지 못한 것으 로 사료된다. 따라서 아동들의 당류 섭취를 줄이기 위한 식생활 개선을 위해서는 흥미도와 학습에 대한 관심을 증대시킬 수 있는 다양한 방법을 적용한 체험형 영양교육 프로그램의 개 발이 요구된다. 울산지역의 초등학생을 대상으로 한 연구에서 재량교육시간에 실시한 영양 
교육이 타 교과에 비해 ‘재미있다’고 응답한 학생들이 ‘보통’ 또는 ‘재미 없다’고 응답한 학생 보다 아침식사의 중요성, 영양 표시와 식품구성탑이 실생활에 도움이 되는 정도에 있어 유의 적으로 높은 점수를 보인 것으로 보고하면서 영양교육의 성과는 학생들이 교육에 대해 만족 할 때 효과가 극대화될 수 있으며, 자신을 교육의 주체로 인식할 때 교육에 대한 만족도 역시 높일 수 있는 것으로 보고하였다 [21].

영양표시제도는 초등학생들을 위한 유용한 영양교육 도구로서 활용이 가능하다고 보고되 고 있으며, Park 등 [22]은 영양표시에 관한 영양교육을 4주에 걸쳐 총 6차례 실시했을 때 교 육 전에 비해 교육군에서만 영양 지식 점수가 향상되었고, 지방함량이 $10 \%$ 이하인 식품 및 가공 우유가 아닌 흰 우유를 선택하는 비율이 유의적으로 증가하였으며, 이러한 변화는 가정 통신문을 통한 간접 교육을 실시한 아동들에서는 관찰되지 않았다. 본 연구에서도 당 교육 인지군에서 가공식품 구입시 당류 함량을 영양표시를 통해 확인한다고 응답한 비율이 비인 지군에 비해 높았다. 영양표시는 일상에서 쉽게 활용할 수 있으며 과도한 당분의 섭취와 비 만 위험도가 높은 미국과 영국 등 여러 서구 국가에서도 가당 음료의 경고 표시 제도를 도입 하고 포장 전면에 당류 함량을 신호등 표시하는 제도를 시행하고 있다 [23]. 본 연구에서 비록 식품의 당류 함량 표시를 확인한 후 식품선택까지 이어진 경우가 당 교육 인지 여부와는 관 련이 없었던 것은 조사대상자가 받은 교육이 지속적으로 진행되지 않고 일회성의 교육이 진 행되었을 것으로 사료된다. 우리나라 초등학생의 경우 대부분의 시간을 학교 교육 및 사교육 에 할애하고 있어 학교나 학원 주변의 문구점이나 편의점 등에서 가공식품을 간식으로 사 먹 는 경우가 많다. 본 연구 역시 간식을 주 1 회 이상 사 먹는 경우가 전체 대상자의 $54.8 \%$ 였고, 약 3\%는 주 7회 이상 거의 매일 사 먹는다고 응답하였고, 회귀분석 결과 간식 구입 빈도가 높 을수록 실제 총 당류 섭취량 역시 높게 나타났다. 따라서 아동들의 구매력 증대와 더불어 아 동들이 자주 이용하는 식품들에 있어 아동들의 눈높이에 맞는 영양표시 제도를 시행하고 이 와 관련한 영양교육 강화를 통해 당 함량의 영양 표시가 초등학생들의 당 섭취량 감소를 유 도할 수 있는 유용한 도구가 될 수 있을 것이다. 현재 식품의약품안전처에서는 당류 저감을 목표로 하여 영양표시 의무 대상 식품을 확대하고 적정 섭취 기준 대비 영양정보를 제공하도 록 하고 있다. 본 연구 결과 영양교육 인지군의 경우 동일한 식품군 내 식품 선택에 있어 당류 가 적게 함유된 식품을 섭취하는 빈도가 상대적으로 높았는데, 이 역시 영양표시를 활용함으 로써 기대되는 효과라고 할 수 있겠다.

본 연구에서 영양 지식과 식행동 간의 상관성은 당 교육 인지 여부에 따라 다르게 나타났는 데, 교육 인지군의 경우 당 지식 점수가 높을수록 아이스크림, 초콜릿, 탄산음료를 적게 먹기 위한 노력을 포함한 전체 식행동 점수와 양의 상관관계를, 간식 구입 빈도와의 음의 상관관 계를 보였으며, 상관계수 값 역시 비인지군에 비해 더 높게 나타났다. 반면, ‘빵을 먹을 때 쨈 을 발라 먹거나 과일을 먹을 때 설탕에 찍어 먹는다와 같은 첨가당 사용 및 하루 평균 당류 섭 취량과의 상관성은 교육 인지군에 비해 비인지군에서 유의적으로 더 높은 상관성을 보였다. 이는 당류 섭취 교육을 통한 영양 지식의 향상은 식품 선택뿐만 아니라 식품 섭취량에 더 큰 영향을 미친다고 할 수 있고, 이에 비해 첨가당의 사용은 당 섭취 교육 여부 보다는 영양지식 자체에 더 밀접한 관련성이 있다고 볼 수 있을 것이다. 당 교육 인지 여부와 관계없이 당 관련 지식 중 가장 정답률이 낮았던 문항은 천연식품 중 당류 함량이 가장 높은 식품을 고르는 문 제였고, 가장 정답률이 높았던 문항은 가공식품 중 당류 함량이 가장 높은 식품을 고르는 문 제였다. 또한 달지 않은 빵류로부터 당류 섭취량이 교육 인지군에서 유의적으로 낮았음에도 
불구하고 흰우유나 생과일로부터의 당류 섭취량이 유의적으로 높아 결과적으로 교육 인지 군과 비인지군 사이의 총 당류 섭취량에는 유의적인 차이가 없었다. 현재 영양표시 제도는 천연당과 첨가당의 구분 없이 총 당류 함량으로 표시되고 있다. 세계보건기구 (World Health Organization, $\mathrm{WHO}$ )에서 당 섭취량의 권고 기준으로 첨가당을 총 열량의 $10 \%$ 미만 섭취할 것 을 권고하고 있으나 [24], 국내에서 발표되고 있는 대부분의 식품영양성분 데이터베이스는 천연당과 첨가당을 구분하지 않고 있어 첨가당의 섭취량 산출이 불가능하여 첨가당에 대한 권고 기준을 평가할 수 없는 실정이다. 천연당은 주로 우유의 유당이나 과일의 과당을 의미 하며, 첨가당은 식품의 제조나 조리 과정 중 첨가되는 설탕, 액상과당, 시럽 및 과즙 농축액을 포함하는 것으로 정의된다 [25]. 우유와 생과일은 당지수가 낮은 대표적인 식품군들이며 유 당은 칼슘 등 무기질 흡수를 촉진시키고 생과일 섭취는 수용성, 불용성 식이섬유 섭취로 당 의 흡수를 억제시켜 오히려 비만과 대사질환의 위험을 낮추고 장내 미생물의 증식을 돕는 효 과가 있는 것으로 알려져 있다 [26,27]. 반면 과일 농축액을 포함하는 무가당 주스의 경우 생 과일에 비해 당지수가 높으며 당뇨병의 위험을 증가시키고 [28], 아동에 있어 충치와 체중 증 가 위험을 증가시키는 것으로 보고되었다 [29]. 그럼에도 불구하고 무가당 주스의 경우 영양 조사나 영양교육에서 과일군으로 분류되고 있어 만성질환과 무가당 주스 섭취에 대한 연구 결과는 부족한 실정이다. 최근 Auerbach 등 [29]은 무가당 주스 섭취와 성인의 만성질환에 대 한 체계적 고찰 연구에서 더 많은 연구결과가 축적될 때까지 영양정책 마련에 있어 무가당 주스를 과일군에 포함시키는 것을 보류해야 한다고 제안하였다. 따라서 아동을 대상으로 한 당 교육에 있어 천연당과 첨가당의 개념과 더불어 가공식품의 형태인 무가당 주스보다는 생 과일 섭취량을 늘릴 수 있도록 교육하는 것이 필요하다 하겠다.

총 당류 섭취량에 영향을 미치는 요인에 대한 회귀분석 결과 교육 인지군에서만 영양(교)사 에 의한 교육 여부와 당 관련 지식 점수가 유의한 영향을 미치는 것으로 나타났고 교육 비인 지군의 경우 이들 요인이 총 당류 섭취량에 영향력이 없는 것으로 나타났다. 본 연구의 설문 조사에 참여한 초등학교는 2016년도에 식품의약품안전처에서 수행하는 당 관련 영양교육 자료를 배부 받아서 영양(교)사에 의해 영양교육을 수행한 학교와 동일한 지역 내 비 참여 학 교를 매칭하여 조사하였다. 그럼에도 불구하고 당 교육 인지군과 비인지군 사이에서 이러한 차이를 보인 이유는 영양(교)사에 의해 당 교육을 실시한 경우 식품의약품안전처의 교육 자 료를 활용하여 당 교육을 시행한 것으로, 영양을 다루는 교과의 일환으로 당 섭취 교육이 이 루어진 경우 보다 더 체계적인 당 교육이 이루어졌기 때문인 것으로 사료된다. 현재 학교급 식법에 의거해 2007년 이후 학교에 영양교사가 배치되고 급식 업무 외에 식생활과 영양교육 을 하도록 규정하고 있고, 어린이 식생활안전관리 특별법이나 식생활교육지원법, 국민영양 관리법 등을 제정해 영양 교육이 강조되고 있다 [30]. 그러나 전국 70개 초등학교 영양교사를 대상으로 한 $\mathrm{Oh}$ 등 [31]의 연구에서 영양교사의 과중한 급식 업무와 표준화된 영양교육 프로 그램의 부재 및 교육시간을 할애 받지 못함 등으로 실제 영양교사에 의한 직접적인 영양교육 을 실시하는 초등학교는 $25.7 \%$ 에 그치는 것으로 보고되었다. 영양교사에 의한 영양교육은 조리실습 또는 시식과 전시 등 체험교육을 포함할 수 있으며, 특히 조리실습은 흥미를 유발 하는 가장 효과적인 영양교육 방법으로 평가되었다 [32]. 따라서 초등학교 아동을 대상으로 체계적인 영양교육을 위하여 독립적으로 운영할 수 있는 영양 교과목의 신설이 필요하며, 영 양교사의 업무 경감과 더불어 교육시수 마련을 위한 제도 정비가 필요할 것으로 생각된다. 또한, 이를 뒷받침할 수 있는 영양교사들의 전문성이 요구되면서 동시에 교육을 효과를 높일 수 있는 영양교육 프로그램의 개발 및 보급이 필요하다 하겠다. 
본 연구는 초등학생을 대상으로 추적조사를 통해 당 교육의 효과 평가를 시도하였다는 점에 의의가 있으나, 당 교육 내용이나 방법에서의 표준화가 일원화되지 못하였고, 1 회성의 당 교 육에 대한 평가를 실시했다는 점, 교육 실시 전 대상자들의 식습관 등에 대한 조사가 이루어 지지 않아 변화를 측정하지 못했다는 점에서 본 연구 결과를 일반화하는데 제한적이라고 할 수 있다. 또한 당류 섭취에 있어 천연당과 첨가당을 구분하지 못했는데, Louie 등 [25]은 식품 을 호주영양소함량 데이터베이스를 토대로 첨가당 함량에 따라 10 단계로 나누어 식품으로 부터의 첨가당 함량을 추정하는 방법을 고안하였다. 이 추정 방식을 적용하여 국내 아동들이 즐겨 섭취하는 식품군과 더불어 표준 레시피를 활용한 음식군의 첨가당 함량 산출을 위한 추 정식을 함께 구축한다면 한국인을 대상으로 한 첨가당 섭취와 관련한 연구에 적용 가능할 것 으로 사료된다. 뿐만 아니라, 본 연구결과 당 교육을 인지한 대상자들이 비인지군에 비해 당 류 함량이 낮은 식품을 섭취하려고 노력하는 것으로 나타나고 있으므로 교육 대상자의 학년 별 특성을 고려한 일회성이 아닌 지속적이고, 지식 중심이 아닌 행동으로 실천할 수 있는 실 천 중심의 영양교육이 수행될 필요가 있으며, 학교 현장에서 영양교사나 영양사뿐만이 아니 라 교과 담당 교사나 담임교사들도 손쉽게 활용할 수 있는 다양한 형태의 영양교육 자료를 정 부차원에서 개발 및 보급되어야 할 것이다. 또한, 어린이들의 식행동은 학교 이외 가정의 식 생활에서도 큰 영향을 받을 수 있으므로 어린이들의 식생활에 영향을 미칠 수 있는 가족 구 성원의 연령별 특성을 고려한 영양교육자료의 개발뿐만 아니라 이들 교육자료를 손쉽게 활 용할 수 있는 매체의 보급 및 홍보가 이루어져야 할 것이다.

\section{요약}

본 연구는 초등학교의 당 관련 영양교육이 당 섭취에 관한 영양지식과 영양태도, 식행동에 어떠한 영향을 미치는지를 평가하기 위해 당 섭취에 관한 설문조사를 실시하였고, 당 교육 인지군과 비인지군으로 나누어 영양지식과 식행동에 어떠한 차이가 있는지를 분석함으로 써 초등학생들의 당류 섭취에 영향을 미치는 요인을 평가하고자 하였으며, 본 연구결과는 다 음과 같다. 본 조사 대상자 중 당 교육을 받았다고 인지한 교육 인지군은 270명 $(49.8 \%)$ 이었 고, 비인지군은 302 명 $(50.2 \%)$ 이었다. 당 교육 인지 여부에 따른 이론적 지식 점수를 보면 교 육 인지군 3.67점, 비인지군 3.55점으로 교육 인지군이 비인지군에 비해 유의적으로 높았으 나, 바른 행동에 대한 지식 점수는 두 군간에 유의적인 차이를 보이지 않았다. 당류 섭취 관련 식행동 점수, 음료 선택 및 간식 구매 빈도는 당 교육 인지 여부에 따른 두 군 간에 유의적인 차이를 보이지 않았으나, 영양표시에서 당류 함량을 확인하는 비율은 교육 인지군이 $31.2 \%$ 로 비인지군 $15.4 \%$ 에 비해 유의적으로 높았다. 아이들이 즐겨 섭취하는 식품군별 섭취 빈도 를 보면 교육 인지군이 비인지군에 비해 무가당 캔디나 젤리류, 생과일류의 섭취 빈도가 유 의적으로 높았으며, 식품군별 당류 섭취량은 달지 않은 빵류, 흰 우유 및 생과일을 통한 당류 섭취량이 비인지군에 비해 교육 인지군에서 유의적으로 높았다. 당 관련 지식 점수와 식행동 사이의 상관성을 보면 교육 인지군의 경우 식행동 점수, 아이스크림, 초콜릿, 탄산음료를 덜 먹으려는 행동과는 양의 상관성을, 방과 후 간식 구입 빈도, 평균 당류 섭취량과는 음의 상관 성을 보였으며, 비인지군의 경우 식행동 점수, 아이스크림, 빵을 먹을 때 잼을 덜 먹는 행동 및 과일 섭취 시 설탕을 덜 먹으려는 식행동과 양의 상관성을, 방과 후 간식구입 빈도 및 당류 섭취량과는 음의 상관성을 보였으나, 비인지군에 비해 교육 인지군에 좀더 높은 상관계수 값 을 보였다. 또한 하루 총 당류 섭취량에 영향을 미치는 요인을 분석한 결과 교육 인지군에서 
만 영양(교)사의 교육 여부가 총 당류 섭취량을 감소시키는 요인으로 분석되었다. 본 연구결 과 당 교육을 인지한 대상자들이 비인지군에 비해 당류 함량이 낮은 식품을 섭취하려고 노력 하는 것으로 나타나고 있으며, 영양교사의 교육 여부가 당류 섭취량에 영향을 미치는 중요한 요인으로 분석되고 있다. 그러므로 초등학생들의 당류 섭취량 감소를 위해서는 학교의 영양 전문가인 영양(교)사에 의해 지속적이고, 행동으로 실천할 수 있는 실천 중심의 영양교육이 수행될 필요가 있으며, 학교 현장에서 손쉽게 활용할 수 있는 다양한 형태의 당 관련 영양교 육 자료의 개발 및 보급이 수행되어야 할 것이다.

\section{REFERENCES}

1. Feig DI. Sugar-sweetened beverages and hypertension. Future Cardiol 2010; 6(6): 773-776. PUBMED | CROSSREF

2. Gross LS, Li L, Ford ES, Liu S. Increased consumption of refined carbohydrates and the epidemic of type 2 diabetes in the United States: an ecologic assessment. Am J Clin Nutr 2004; 79(5): 774-779. PUBMED | CROSSREF

3. Kosova EC, Auinger P, Bremer AA. The relationships between sugar-sweetened beverage intake and cardiometabolic markers in young children. J Acad Nutr Diet 2013; 113(2): 219-227. PUBMED | CROSSREF

4. Lee EJ, Hwang IK, Jin BH, Paik DI. Correlation between snack food intakes and dental caries in elementary school children. Korean J Food Cookery Sci 2008; 24(2): 251-257.

5. Lee HS, Kwon SO, Yon M, Kim D, Lee JY, Nam J, et al. Dietary total sugar intake of Koreans: Based on the Korea National Health and Nutrition Examination Survey (KNHANES), 2008-2011. J Nutr Health 2014; 47(4): 268-276. CROSSREF

6. Ha K, Chung S, Joung H, Song Y. Dietary sugar intake and dietary behaviors in Korea: a pooled study of 2,599 children and adolescents aged 9-14 years. Nutr Res Pract 2016; 10(5): 537-545. PUBMED | CROSSREF

7. Ko YS, Kim EM, Lee HS. A study of dietary intake of total sugars by elementary students in Jeju province. J Nutr Health 2015; 48(1): 81-93. CROSSREF

8. Kim SY, Kim MH, Kang MH, Choi MK. Association of total sugars intake with nutrient density and obesity degree in elementary school students in Chungnam. J East Asian Soc Diet Life 2017; 27(2): 176-184. CROSSREF

9. Ludwig DS, Peterson KE, Gortmaker SL. Relation between consumption of sugar-sweetened drinks and childhood obesity: a prospective, observational analysis. Lancet 2001; 357(9255): 505-508. PUBMED | CROSSREF

10. Millar L, Rowland B, Nichols M, Swinburn B, Bennett C, Skouteris H, et al. Relationship between raised BMI and sugar sweetened beverage and high fat food consumption among children. Obesity (Silver Spring) 2014; 22(5): E96-E103. PUBMED | CROSSREF

11. Hur YI, Park H, Kang JH, Lee HA, Song HJ, Lee HJ, et al. Associations between sugar intake from different food sources and adiposity or cardio-metabolic risk in childhood and adolescence: the Korean ChildAdolescent Cohort Study. Nutrients 2015; 8(1): 20-37. PUBMED | CROSSREF

12. An M, An H, Hwang HJ, Kwon HJ, Ha M, Hong YC, et al. Dietary factors associated with attention deficit hyperactivity disorder (ADHD) in school-aged children. Korean J Community Nutr 2018; 23(5): 397-410. CROSSREF

13. Ministry of Food and Drug Safety (KR). The first comprehensive plan for the sugar reduction ('16-'20). Osong: Ministry of Food and Drug Safety; 2016.

14. The National Law Information Center. Special act on safety management of children's dietary lifestyle [Internet]. Sejong: Korea Ministry of Government Legislation; 2020 [cited 2020 Jan 14]. Available from: http://www.law.go.kr/\%EB\%B2\%95\%EB\%A0\%B9/\%EC\%96\%B4\%EB\%A6\%B0\%EC\%9D\%B4\%EC\%8B \%9D\%EC\%83\%9D\%ED\%99\%9C\%EC\%95\%88\%EC\%A0\%84\%EA\%B4\%80\%EB\%A6\%AC\%ED\%8A\%B 9\%ЕВ\%В3\%84\%ЕВ\%В2\%95. 
15. Kang MH, Lee JS, Kim HY, Kwon S, Choi YS, Chung HR, et al. Selecting items of a food behavior checklist for the development of Nutrition Quotient (NQ) for children. Korean J Nutr 2012; 45(4): 372-389. CROSSREF

16. Korea Health Industry Development Institute, Ministry of Food and Drug Safety (KR). Sugar database compilation for commonly consumed foods. Cheongju: Korea Health Industry Development Institute; 2015.

17. Park DY. Theory and model applying for nutrition education. Korean J Community Nutr 1997; 2(1): 97-104.

18. Lee JW, Lee HS, Chang N, Kim JM. The relationship between nutrition knowledge scores and dietary behavior, dietary intakes and anthropometric parameters among primary school children participating in a nutrition education program. Korean J Nutr 2009; 42(4): 338-349. CROSSREF

19. Lee O, Chang SO, Park MJ. Comparison of nutrition knowledge, dietary attitude and dietary habit in elementary school children with and without nutrition education. J Korean Soc Food Sci Nutr 2008; 37(11): 1427-1434. CROSSREF

20. Han HM, Lee SS. A nutrition education program development and the application for the elementary students: focused on sugar intake education. J Korean Pract Arts Educ 2008; 21(2): 111-131.

21. Yun JS, Lyu ES. Satisfaction and perception of nutrition education by elementary school students. J Korean Soc Food Sci Nutr 2012; 41(9): 1259-1264. CROSSREF

22. Park HJ, Lee JS, Kim EK. Assessment of nutrition label education in sixth grade elementary school students. J Korean Diet Assoc 2010; 16(3): 226-238.

23. National Food Safety Information Service (NFIS). Current status of sugar reduction in major countries (focused on sugar tax). Food Safety Policy Research Report 2017-05. Seoul: National Food Safety Information Service; 2017.

24. World Health Organization (WHO). Guideline: sugars intake for adults and children. Geneva: World Health Organization; 2015.

25. Louie JC, Moshtaghian H, Boylan S, Flood VM, Rangan AM, Barclay AW, et al. A systematic methodology to estimate added sugar content of foods. Eur J Clin Nutr 2015; 69(2): 154-161. PUBMED | CROSSREF

26. Ford ES, Mokdad AH. Fruit and vegetable consumption and diabetes mellitus incidence among U.S. adults. Prev Med 2001; 32(1): 33-39. PUBMED | CROSSREF

27. Bazzano LA, He J, Ogden LG, Loria CM, Vupputuri S, Myers L, et al. Fruit and vegetable intake and risk of cardiovascular disease in US adults: the first National Health and Nutrition Examination Survey Epidemiologic Follow-up Study. Am J Clin Nutr 2002; 76(1): 93-99. PUBMED | CROSSREF

28. Bazzano LA, Li TY, Joshipura KJ, Hu FB. Intake of fruit, vegetables, and fruit juices and risk of diabetes in women. Diabetes Care 2008; 31(7): 1311-1317. PUBMED | CROSSREF

29. Auerbach BJ, Dibey S, Vallila-Buchman P, Kratz M, Krieger J. Review of $100 \%$ fruit juice and chronic health conditions: implications for sugar-sweetened beverage policy. Adv Nutr 2018; 9(2): 78-85. PUBMED | CROSSREF

30. Hwang $\mathrm{O}$. The actual condition and needs on nutritional education among school nutrition teachers in Chonbuk province [master's thesis]. Jeonju: Jeonbuk National University; 2012.

31. Oh NG, Gwon SJ, Kim KW, Sohn CM, Park HR, Seo JS. Status and need asessment on nutrition \& dietary life education among nutrition teachers in elementary, middle and high schools. Korean J Community Nutr 2016; 21(2): 152-164. CROSSREF

32. Kim HS. A survey on nutrition education activities by nutrition teachers of elementary school in Incheon area [master's thesis]. Incheon: Inha University; 2012. 